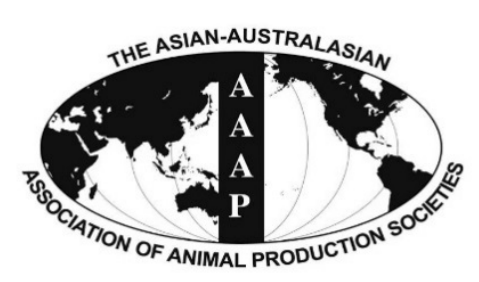

Open Access

Asian Australas. J. Anim. Sci.

Vol. 29, No. 10 : 1464-1469 October 2016

http://dx.doi.org/10.5713/ajas.15.0664

www.ajas.info

pISSN 1011-2367 elSSN 1976-5517

\title{
Effect of Dietary Supplementation of Red Ginseng By-product on Laying Performance, Blood Biochemistry, Serum Immunoglobulin and Microbial Population in Laying Hens
}

\author{
H. K. Kang, S.-B. Park, and C. H. Kim* \\ Poultry Science Division, National Institute of Animal Science, RDA, Cheonan 331-801, Korea
}

\begin{abstract}
This study was carried out to investigate the effect of dietary supplementation of red ginseng by-product (RGB) on the laying performance, blood biochemistry, and microbial population in laying hens. A total of 120 Hy-Line Brown laying hens (75 weeks old) were randomly allotted to 1 of 3 dietary treatments with 4 replicates per treatment. A commercial-type basal diet was prepared, and 2 additional diets were prepared by supplementing 5.0 or $10.0 \mathrm{~g} / \mathrm{kg}$ of RGB to the basal diet at the expense of corn. The diets were fed to hens on an ad libitum basis for 4 weeks. There were no differences in feed intake, egg weight, and feed conversion ratio during 4 weeks of the feeding trial. However, hen-day egg production was significantly greater $(p<0.05)$ for the RGB treatment groups than that for the basal treatment group. There were no differences in triglyceride, aspartate aminotransferase, and alanine aminotransferase during the 4week feeding trial. However, RGB supplementation increased $(\mathrm{p}<0.05)$ the serum immunoglobulin G (IgG) and IgM content compared with basal treatment group. The total cholesterol was lower $(\mathrm{p}<0.05)$ in the RGB treatments groups than that in the basal treatment group. The intestinal Lactobacillus population was greater $(\mathrm{p}<0.05)$ for the RGB treatments groups than that for the basal treatment group. However, the numbers of Salmonella and Escherichia coli were not different among dietary treatments. During the entire experiment, there was no significant difference in egg quality among all the treatments. In conclusion, in addition to improving hen-day production, there were positive effects of dietary RGB supplementation on serum immunoglobulin and cholesterol levels in laying hens. (Key Words: Red Ginseng By-product, Laying Hen, Laying Performance, Serum Cholesterol)
\end{abstract}

\section{INTRODUCTION}

Ginseng (Panax ginseng Meyer) is a traditional medicinal plant, and has been widely used over 2,000 years in Korea, Japan, and China (Szeto et al., 2010). Ginseng contains saponin, ginsenosides, essential oils, polyacetylenic alcohol, peptides, vitamins, and polysaccharides (Cheung et al., 2007; Kang et al., 2007; Jin et al., 2008; Wee et al., 2011). Various beneficial pharmacological effects of ginseng or its components have been reported, including anti-cancer, anti-allergy, anti-inflammatory, anti-fatigue, anti-stress, and immunomodulatory activities (Kim et al., 2002; Park et al, 2004; Sumiyoshi et al., 2010; Lee and Cho, 2011). Red ginseng is produced by steaming fresh ginseng

\footnotetext{
* Corresponding Author: C. H. Kim. Tel: +82-41-580-6729, E-mail: kch8059@korea.kr

Submitted Aug. 12, 2015; Revised Oct. 14, 2015; Accepted Nov. 13, 2015
}

at $95^{\circ} \mathrm{C}$ to $100^{\circ} \mathrm{C}$ for a reasonable time (Kim et al., 2009). It is known to have greater pharmaceutical efficacy and functionality than white ginseng, due to its high saponin content (Kim and In, 2010). Also, red ginseng may be useful for the treatment of hypertension and pulmonary vascular obstruction (Han et al., 2005) and has immune stimulatory and antioxidant activity as well as vasorelaxing effects in several arterial vessels (Gillis, 1997; Shin et al., 2000). Previous studies with animals have demonstrated the potential effects of ginseng as an immunization agent against various pathogens ( $\mathrm{Hu}$ et al., 2003; Rivera et al., 2003). For example, dietary supplementation of red ginseng extracts has been shown to improve egg production of laying hens (Jang et al., 2007; Kim et al., 2015). Many studies have indicated that saponin is a potentially bioactive ingredient of red ginseng (Ao et al., 2011). The extraction of red ginseng creates by-product has a potential bioactive 
and immunostimulant additive to animal feed. To the best of our knowledge, limited research has been published on the effects of dietary red ginseng marc on immune system and the intestinal microflora of laying hens. Therefore, this study was performed to investigate the effects of dietary red ginseng by-product (RGB) supplementation on egg production, egg quality, blood biochemistry, serum immunoglobulins and microbial population in laying hens.

\section{MATERIALS AND METHODS}

The protocol for this experiment was reviewed and approved by the Institutional Animal Care and Welfare Committee of the National Institute of Animal Science, Rural Development Administration, Korea.

\section{Preparation of red ginseng by-product}

The RGB was obtained from Korean Ginseng Nonghyup (Geumsan, Korea). RGB was first dried and ground finely using a Wiley mill (J-NCM, Jisico Co. Ltd., Seoul, Korea). RGB saponins were extracted according to the method described in the previous research (Sung and Lee, 2008). The nutrient composition of the RGB was analyzed in duplicate for dry matter (AOAC, 1990; method 934.01), crude ash (AOAC, 1990; method 934.01), crude fat (AOAC, 1990; method 942.05), crude protein (AOAC, 1990; method 988.05), and crude fiber (AOAC, 1990; method; 978.01), and the results are presented in Table 1.

\section{Birds and experimental design}

A total of 120, 75-week-old Hy-Line Brown laying hens were randomly allotted to 1 of 3 dietary treatments. Each treatment had 4 replicates with 5 cages and 2 hens per cage $(30 \times 37 \times 40 \mathrm{~cm}=$ width $\times$ length $\times$ height $)$. A commercial type basal diet was formulated to meet or exceed nutrient recommendations of the National Research Council (NRC, 1994) for laying hens (Table 2). Two additional diets were prepared by supplementing 5.0 or $10.0 \mathrm{~g} / \mathrm{kg}$ of RGB to the basal diet at the expense of corn. The experimental period was 4 weeks. During the experiment, hens were provided with feed and water ad libitum and were exposed to a 16-

Table 1. Analyzed composition of red ginseng by-product

\begin{tabular}{lc}
\hline Items & Red ginseng by-product $^{1}$ \\
\hline Dry matter $(\mathrm{g} / \mathrm{kg})$ & 966.8 \\
Crude fat $(\mathrm{g} / \mathrm{kg})$ & 12.0 \\
Crude fiber $(\mathrm{g} / \mathrm{kg})$ & 153.6 \\
Crude protein $(\mathrm{g} / \mathrm{kg})$ & 142.5 \\
Crude ash $(\mathrm{g} / \mathrm{kg})$ & 29.5 \\
Total saponin $(\mathrm{mg} / \mathrm{g})$ & 0.62 \\
\hline
\end{tabular}

\footnotetext{
${ }^{1}$ Nutrient composition was analyzed in duplicate for dry matter (AOAC, 1990; method 934.01), crude fat (AOAC, 1990; method 920.39), crude fiber (AOAC, 1990; method 978.10), crude protein (AOAC 1990; method 988.05).
}

Table 2. Composition and nutrient content of experimental diets

\begin{tabular}{lccc}
\hline Items & RGB 0.0 & RGB 5.0 & RGB 10.0 \\
\hline Ingredients $(\mathrm{g} / \mathrm{kg})$ & & & \\
Corn & 411.5 & 406.5 & 401.5 \\
Wheat & 150.0 & 150.0 & 150.0 \\
Soybean meal & 250.0 & 250.0 & 250.0 \\
DDGS & 50.0 & 50.0 & 50.0 \\
Canola meal & 20.0 & 20.0 & 20.0 \\
Tallow & 5.0 & 5.0 & 5.0 \\
Molasses & 5.0 & 5.0 & 5.0 \\
Dicalcium phosphate & 7.0 & 7.0 & 7.0 \\
Limestone & 97.0 & 97.0 & 97.0 \\
Sodium chloride & 2.0 & 2.0 & 2.0 \\
Red ginseng by-product & - & 5.0 & 10.0 \\
Vitamin premix ${ }^{1}$ & 1.5 & 1.5 & 1.5 \\
Mineral premix & & 1.0 & 1.0 \\
Total & 1.0 & 1.0 & $1,000.0$ \\
Energy and nutrient content ${ }^{3}$ & $1,000.0$ & $1,000.0$ & \\
MEn $(\mathrm{MJ} / \mathrm{kg})$ & 11.4 & 11.4 & 11.4 \\
Crude protein $(\mathrm{g} / \mathrm{kg})$ & 142.0 & 142.0 & 142.0 \\
Calcium $(\mathrm{g} / \mathrm{kg})$ & 45.0 & 45.0 & 45.0 \\
Available P $(\mathrm{g} / \mathrm{kg})$ & 3.3 & 3.3 & 3.3 \\
Lysine $(\mathrm{g} / \mathrm{kg})$ & 7.5 & 7.5 & 7.5 \\
Methionine $(\mathrm{g} / \mathrm{kg})$ & 3.6 & 3.6 & 3.6 \\
\hline RB & & & \\
\hline
\end{tabular}

RGB, red ginseng by-product; DDGS, distillers dried grains with soluble; $\mathrm{ME}_{\mathrm{n}}$, nitrogen-corrected metabolizable energy.

1 Provided per kilogram of the complete diet: vitamin A (vitamin A acetate), 12,500 IU; vitamin $\mathrm{D}_{3}, 2,500 \mathrm{IU}$; vitamin $\mathrm{E}$ (DL- $\alpha$-tocopheryl acetate), $20 \mathrm{IU}$; vitamin $\mathrm{K}_{3}, 2 \mathrm{mg}$; vitamin $\mathrm{B}_{1}, 2 \mathrm{mg}$; vitamin $\mathrm{B}_{2}, 5 \mathrm{mg}$; vitamin $\mathrm{B}_{6}, 3 \mathrm{mg}$; vitamin $\mathrm{B}_{12}, 18 \mu \mathrm{g}$; calcium pantothenate, $8 \mathrm{mg}$; folic acid, $1 \mathrm{mg}$; biotin, $50 \mu \mathrm{g}$; niacin, $24 \mathrm{mg}$.

${ }^{2}$ Provided per kilogram of complete diet: $\mathrm{Fe}\left(\mathrm{FeSO}_{4} \cdot 7 \mathrm{H}_{2} \mathrm{O}\right), 40 \mathrm{mg} ; \mathrm{Cu}$ $\left(\mathrm{CuSO}_{4} \cdot \mathrm{H}_{2} \mathrm{O}\right), 8 \mathrm{mg} ; \mathrm{Zn}\left(\mathrm{ZnSO}_{4} \cdot \mathrm{H}_{2} \mathrm{O}\right), 60 \mathrm{mg} ; \mathrm{Mn}\left(\mathrm{MnSO}_{4} \cdot \mathrm{H}_{2} \mathrm{O}\right) 90 \mathrm{mg}$; $\mathrm{Mg}(\mathrm{MgO})$ as $1,500 \mathrm{mg}$.

${ }^{3}$ Nutrient contents in all diet were calculated.

$\mathrm{h}: 8$-h light:dark lighting schedule. The temperature and humidity of the laying house was maintained at $18^{\circ} \mathrm{C} \pm 3^{\circ} \mathrm{C}$ and $65 \%$ to $70 \%$, respectively, during the experiment.

\section{Laying performance and egg quality}

Hen-day egg production rate and egg weight were recorded daily, whereas feed intake and feed conversion ratio were recorded weekly. Ten eggs per replicate were randomly collected at the end of the each week to measure eggshell strength, eggshell thickness, eggshell color, and Haugh units (HU). Eggshell strength was measured by the Texture Systems compression test cell (model T2100C, Food Technology Co., Ltd., Rockville, MD, USA) and was expressed as units of compression force exposed to units of eggshell surface area $\left(\mathrm{kg} / \mathrm{cm}^{2}\right)$. Eggshell thickness (without the inner and outer shell membrane) was determined at three different points (top, middle, and bottom) using a dial pipe gauge (model 7360, Mitutoyo Co. Ltd., Kawasaki, Japan) without cracking the eggshell. Egg yolk color was 
evaluated by the Roche color fan (Hoffman-La Roche Ltd., Basel, Switzerland; $15=$ dark orange; $1=$ light pale). The $\mathrm{HU}$ values were calculated using a micrometer (model S8400, Ames, Waltham, MA, USA) from the following formula described by Eisen et al. (1965): $\mathrm{HU}=100 \log (\mathrm{H}-$ $\left.1.7 \mathrm{~W}^{0.37}+7.6\right)$, where $\mathrm{W}$ is egg weight and $\mathrm{H}$ is albumen height.

\section{Sample collection}

At the end of the 28-day feeding trial, 2 birds/replicate with a body weight close to the average (i.e., 8 birds per treatment) were selected to be euthanized by cervical dislocation. Immediately after death, a 5-mL blood sample was collected from the jugular vein of each bird using ethylenediaminetetraacetic acid vacuum tubes (Becton Dickinson, Franklin Lakes, NJ, USA), and stored on ice. Serum samples, obtained by centrifuging the samples for 20 $\min$ at $25,000 \times g$ and $4{ }^{\circ} \mathrm{C}$, were stored at $-15^{\circ} \mathrm{C}$. Aspartate aminotransferase (AST), alanine aminotransferase (ALT), triglyceride, and total cholesterol in the serum were quantified using an ADVIA 1650 chemistry system (Bayer Diagnostic, Putraux, France). The cecal contents were collected from the euthanized chickens and used for analyzing bacterial populations. The cecum was ligated at both sides and removed from the gastrointestinal tract, and the contents were aseptically collected into a 2-mL Eppendorf tube. The cecal contents were immediately frozen at $-80^{\circ} \mathrm{C}$ before analysis.

\section{Measurement of serum IgG and IgM concentration}

The plasma samples were used to measure the concentrations of immunoglobulin ( $\mathrm{IgG})$ and $\operatorname{IgM}$ isotypes by using chicken $\operatorname{IgG}$, IgA, and IgM enzyme-linked immunosorbent assay quantification kits, respectively (Bethyl Laboratories, Montgomery, TX, USA). Briefly, flatbottomed microtiter plates were coated for $60 \mathrm{~min}$ with capture antibody (purified goat anti-chicken $\operatorname{IgG}$ or $\operatorname{IgM}$ ) and coating buffer ( $0.05 \mathrm{M}$ carbonate-bicarbonate, $\mathrm{pH} 9.6)$. They were washed 3 times with washing solution $(50 \mathrm{mM}$ Tris-buffered saline, $0.14 \mathrm{M} \mathrm{NaCl}, 0.05 \%$ Tween 20 , pH 8.0); subsequently, blocking solution (50 mM Tris-buffered saline, $0.14 \mathrm{M} \mathrm{NaCl}, 1 \%$ bovine serum albumin (BSA), $\mathrm{pH}$ 8.0) was added to the wells for $30 \mathrm{~min}$, and then the wells were rinsed 3 times with washing solution. The calibrator (chicken reference plasma) and sample-conjugate diluent (50 mM Tris-buffered saline, $0.14 \mathrm{mM} \mathrm{NaCl}, 1 \%$ BSA, $0.05 \%$ Tween $20, \mathrm{pH} 8.0$ ) were used to prepare standards, whereas plasma samples, which were thawed at $4^{\circ} \mathrm{C}$ overnight, were diluted at 1:1,000 in the sample-conjugate diluent. Subsequently, they were added to the wells for 60 min and washed 5 times with washing solution. The detection antibody horseradish peroxidase (goat antichicken $\operatorname{IgG}$, or IgM) diluted in sample-conjugate diluent was added to the wells, incubated for $60 \mathrm{~min}$, and rinsed 5 times with washing solution. Next, the enzyme substrate $\left(3,3^{\prime}, 5,5^{\prime}\right.$-tetramethyl benzidine peroxidase substrate and peroxidase solution B) was added, and the samples were incubated for $15 \mathrm{~min}(\mathrm{IgM})$ or $30 \mathrm{~min}(\mathrm{IgG})$. Finally, $2 \mathrm{M}$ $\mathrm{H}_{2} \mathrm{SO}_{4}$ was used to stop the enzyme substrate reaction. A microtiter plate reader (Spectramax 190; Molecular Device, Salt Lake City, UT, USA) was used to measure the absorbance at $450 \mathrm{~nm}$. The immunoglobulin (IgG or IgM) titers were determined by developing a four-parameter logistic curve fit by using the Hy-line brown laying hen reference plasma absorbance.

\section{Measurement of microbial populations}

The composite cecal material sample ( $1 \mathrm{~g})$ of each hen was diluted with $9 \mathrm{~mL}$ of $0.9 \%$ saline solution and mixed using a vortex. Viable counts of bacteria in the cecal samples were then estimated by plating serial 10 -fold dilutions (in 1\% peptone solution) on lactobacilli de Man, Rogosa, and Sharpe (Lactobacilli MRS), MacConkey, and Salmonella shigella agar plates (Difco Laboratories, Becton Dickinson, Franklin Lakes, NJ, USA) in order to isolate Lactobacillus, Escherichia coli, and Salmonella, respectively. The Lactobacilli MRS plates were then incubated for $48 \mathrm{~h}$ at $37^{\circ} \mathrm{C}$ under anaerobic conditions, and the MacConkey and Salmonella shigella plates were incubated for $24 \mathrm{~h}$ at $37^{\circ} \mathrm{C}$ under aerobic conditions. Lactobacillus, E. coli, and Salmonella colonies were counted immediately after removal from the incubator.

\section{Statistical analysis}

All data were analyzed by one-way analysis of variance as a completely randomized design using the PROC MIXED procedure (SAS Institute Inc., Cary, NC, USA). Outlier data were identified by the UNIVARIATE procedure of SAS, but no outliers were found. Least squares means were calculated and the means among treatments were compared by the PDIFF option with the Tukey adjustment. Significance was set at $\mathrm{p}<0.05$.

\section{RESULTS AND DISCUSSION}

There were no differences in feed intake, egg weight, and feed conversion ratio during the 4 weeks of the feeding trial among groups. However, hen-day egg production was greater $(p<0.05)$ for RGB treatment groups than that for basal treatment group, and no significant differences were observed among the RGB treatment groups (Table 3). It was previously suggested that ginseng may improve physiological function and immunity, and exerts various pharmacological effects (Kiefer and Pantuso, 2003). Therefore, a beneficial influence of RGB on performance was expected. Jang et al. (2007) and Kim et al. (2015) 
Table 3. Laying performance of layers fed the diet containing red ginseng by-product ${ }^{1}$

\begin{tabular}{|c|c|c|c|c|c|}
\hline \multirow{3}{*}{ Items } & \multicolumn{3}{|c|}{ Dietary treatment ${ }^{2}$} & \multirow{3}{*}{ SEM } & \multirow{3}{*}{ p-value } \\
\hline & RGB & RGB & RGB & & \\
\hline & 0.0 & & 10.0 & & \\
\hline $\begin{array}{l}\text { Hen-day egg } \\
\text { production (\%) }\end{array}$ & $75.9^{\mathrm{b}}$ & $82.1^{\mathrm{a}}$ & $82.6^{\mathrm{a}}$ & 0.30 & 0.04 \\
\hline Feed intake $(\mathrm{g} / \mathrm{d} / \mathrm{hen})$ & 150.3 & 151.8 & 156.6 & 1.69 & 0.82 \\
\hline Egg weight (g) & 64.4 & 63.7 & 66.1 & 0.32 & 0.59 \\
\hline $\begin{array}{l}\text { Feed conversion ratio } \\
(\mathrm{g} / \mathrm{g})\end{array}$ & 3.07 & 3.03 & 3.01 & 0.04 & 0.49 \\
\hline \multicolumn{6}{|c|}{$\begin{array}{l}\text { RGB, red ginseng by-product; SEM, pooled standard error of means. } \\
{ }^{1} \text { Data are least squares means of } 4 \text { observations per treatments. } \\
{ }^{2} \text { Basal diet was supplemented at the level of red ginseng by-product } 5.0 \\
\text { or } 10.0 \mathrm{~g} / \mathrm{kg} \text { to the diets, respectively. } \\
\text { a,b Values with different superscripts in the same row are significantly } \\
\text { different }(\mathrm{p}<0.05) \text {. }\end{array}$} \\
\hline
\end{tabular}

reported that fermented wild ginseng culture by-product or red ginseng extracts could increase egg production, which may be attributed to the improvement in the health status of birds fed diets supplemented with ginseng. Jenkins and Atwal (1994) suggested that dietary saponins (main bioactive compounds in ginseng) had adverse effects on growth performance and feed intake of chicks due to their bitter taste. In contrast, no reduction of feed intake due to RGB supplementation was observed in the current experiment. Due to the limited experiments on ginseng in livestock, further studies are needed to be conducted.

In addition, the supplementation of RGB did not have an effect on eggshell strength, eggshell thickness, egg yolk color, and HU during the feeding trial (Table 4). Similar to the present study, Ao et al. (2011) reported that egg qualities were not affected by the supplementation level of red ginseng extracts. However, Jang et al. (2007) observed that supplemented red ginseng could improve egg quality compared to the basal treatment. These conflicting results may be due to different strains, ginseng sources, or methods of their preparation, as reported by Ao et al. (2011). There were no differences in triglyceride, AST, and ALT levels

Table 4. Eggshell quality of layers fed the diet containing red ginseng by-product (RGB) ${ }^{1}$

\begin{tabular}{|c|c|c|c|c|c|}
\hline \multirow{3}{*}{ Items } & \multicolumn{3}{|c|}{ Dietary treatment $^{2}$} & \multirow{3}{*}{ SEM } & \multirow{3}{*}{ p-value } \\
\hline & RGB & RGB & RGB & & \\
\hline & 0.0 & 5.0 & 10.0 & & \\
\hline $\begin{array}{l}\text { Eggshell strength } \\
\left(\mathrm{kg} / \mathrm{cm}^{2}\right)\end{array}$ & 3.40 & 3.30 & 3.40 & 0.11 & 0.25 \\
\hline $\begin{array}{l}\text { Eggshell thickness } \\
(\mu \mathrm{m})\end{array}$ & 351.0 & 352.0 & 360.9 & 4.35 & 0.45 \\
\hline Egg yolk color & 8.0 & 8.8 & 8.6 & 0.10 & 0.68 \\
\hline Haugh unit & 83.5 & 83.8 & 82.9 & 0.84 & 0.50 \\
\hline
\end{tabular}

SEM, pooled standard error of means.

${ }^{1}$ Data are least squares means of 4 observations per treatments.

${ }^{2}$ Basal diet was supplemented at the level of red ginseng by-product 5.0 or $10.0 \mathrm{~g} / \mathrm{kg}$ to the diets, respectively.
Table 5. Blood biochemical parameters of layers fed the diet containing red ginseng by-product $(\mathrm{RGB})^{1}$

\begin{tabular}{lccccc}
\hline \multirow{2}{*}{ Items } & \multicolumn{3}{c}{ Dietary treatment } & & \\
\cline { 2 - 4 } & $\begin{array}{c}\text { RGB } \\
0.0\end{array}$ & $\begin{array}{c}\text { RGB } \\
5.0\end{array}$ & $\begin{array}{c}\text { RGB } \\
10.0\end{array}$ & SEM & p-value \\
\hline $\begin{array}{c}\text { Total cholesterol } \\
(\mathrm{mg} / \mathrm{dL})\end{array}$ & $251.3^{\mathrm{a}}$ & $238.7^{\mathrm{b}}$ & $235.1^{\mathrm{b}}$ & 1.35 & 0.04 \\
$\begin{array}{c}\text { Triglyceride } \\
(\mathrm{mg} / \mathrm{dL})\end{array}$ & 266.7 & 265.1 & 258.5 & 1.02 & 0.19 \\
$\begin{array}{c}\text { AST (U/L) } \\
\text { ALT (U/L) }\end{array}$ & 141.7 & 142.5 & 140.8 & 0.59 & 0.31 \\
\hline
\end{tabular}

SEM, pooled standard error of means.

${ }^{1}$ Data are least squares means of 4 observations per treatments.

${ }^{2}$ Basal diet was supplemented at the level of red ginseng by-product 5.0 or $10.0 \mathrm{~g} / \mathrm{kg}$ to the diets, respectively.

a,b Values with different superscripts in the same row are significantly different $(\mathrm{p}<0.05)$.

during the 4 weeks of the feeding trial (Table 5). However, the serum IgG and IgM concentrations of the chickens fed RGB supplemented diet were $10.5 \%$ and $29.14 \%$ higher than those in the basal treatment group respectively, whereas no significant differences were observed among the RGB treatment groups (Table 6). Hu et al. (2003) reported that RGB could have a beneficial effect on immune function. This study also showed that RGB may have positive effect on the immune system of laying hens.

In the current experiment, reduced serum cholesterol by RGB supplementation in the diets is likely caused by the inhibition of cholesterol or bile acid absorption as was observed with ginseng feeding (Oakenfull and Sidhu, 1990). Some saponins form insoluble complexes with cholesterol in the digesta and inhibit the intestinal absorption of endogenous and exogenous cholesterol (Rao and Gurfinkel, 2000). Previous experiments suggested that dietary ginseng impaired avian hepatic cholesterogensis and reduced serum total cholesterol (Qureshi et al., 1983; Muwalla and Abuirmelieh, 1990). Jang et al. (2007) reported that total cholesterol was decreased by supplementation of red ginseng extracts in the diet of laying hens. The concentration of Lactobacillus was greater $(p<0.05)$ in the RGB treatments groups than that in the basal treatment

Table 6. Serum immunoglobulin ( $\mathrm{Ig}$ ) of layers fed the diets containing red ginseng by-product (RGB) ${ }^{1}$

\begin{tabular}{lccccc}
\hline \multirow{2}{*}{ Items } & \multicolumn{3}{c}{ Dietary treatment ${ }^{2}$} & \multirow{2}{*}{ SEM } & \multirow{2}{*}{ p-value } \\
\cline { 2 - 4 } & RGB 0.0 & RGB 5.0 & RGB 10.0 & & \\
\hline $\operatorname{IgM}(\mu \mathrm{g} / \mathrm{mL})$ & $173.75^{\mathrm{b}}$ & $190.28^{\mathrm{a}}$ & $192.13^{\mathrm{a}}$ & 10.25 & 0.41 \\
$\operatorname{IgG}(\mu \mathrm{g} / \mathrm{mL})$ & $78.34^{\mathrm{b}}$ & $100.16^{\mathrm{a}}$ & $101.17^{\mathrm{a}}$ & 8.13 & 0.32 \\
\hline
\end{tabular}

SEM, pooled standard error of means.

${ }^{1}$ Data are least squares means of 4 observations per treatments.

${ }^{2}$ Basal diet was supplemented at the level of red ginseng by-product 5.0 or $10.0 \mathrm{~g} / \mathrm{kg}$ to the diets, respectively.

a,b Values with different superscripts in the same row are significantly different $(\mathrm{p}<0.05)$. 
Table 7. Intestinal microflora of layers fed the diets containing red ginseng by-product (RGB) ${ }^{1}$

\begin{tabular}{lccccc}
\hline \multirow{2}{*}{ Items } & \multicolumn{3}{c}{ Dietary treatment ${ }^{2}$} & \multirow{2}{*}{ SEM } & $\begin{array}{c}\text { p- } \\
\text { value }\end{array}$ \\
\cline { 2 - 4 } & RGB 0.0 & RGB 5.0 & RGB 10.0 & & \\
Lactobacillus & $5.17^{\mathrm{b}}$ & $5.49^{\mathrm{a}}$ & $5.63^{\mathrm{a}}$ & 0.13 & 0.04 \\
Salmonella & 4.66 & 4.55 & 4.56 & 0.45 & 0.56 \\
Escherichia coli & 4.23 & 4.25 & 4.30 & 0.35 & 0.19 \\
\hline SEM, pooled standard error of means. \\
${ }^{1}$ Data are least squares means of 4 observations per treatments. \\
${ }^{2}$ Basal diet was supplemented at the level of red ginseng by-product 5.0 \\
or 10.0 g/kg to the diets, respectively. \\
a,b Values with different superscripts in the same row are significantly \\
different $(\mathrm{p}<0.05)$.
\end{tabular}

group, whereas no significant differences were observed among the RGB treatment groups (Table 7). The concentrations of Salmonella and E. coli in the ileum were not affected by inclusion of RGB in the diets.

The results of this study indicated that dietary supplementation of RGB improves laying performance and decreases serum cholesterol levels. The results also showed that RGB may be utilized as an immunostimulant for laying hens. Therefore, RGB can be considered as a potential functional ingredient to improve egg production and immune response of laying hens.

\section{CONFLICT OF INTEREST}

We certify that there is no conflict of interest with any financial organization regarding the material discussed in the manuscript.

\section{ACKNOWLEDGMENTS}

This work was carried out with the support of the "Cooperative Research Program for Agriculture Science \& Technology Development (Project title: Development of technical skills to improve older laying hens meat quality for export invigoration, Project No. PJ008409)", Rural Development Administration, Republic of Korea.

\section{REFERENCES}

AOAC. 1990. Official Methods of Analysis. 15th edn. Association of Official Analytical Chemists, Aarlington, VA, USA.

Ao, X., T. X. Zhou, H. J. Kim, S. M. Hong, and I. H. Kim. 2011. Influence of fermented red ginseng extract on broilers and laying hens. Asian Australas. J. Anim. Sci. 24:993-1000.

Cheung, S. C. M., Y. T. Szeto, and I. F.F. Benzie. 2007. Antioxidant protection of edible oils. Plant Foods Hum. Nutr. 62:39-42.

Eisen, E. J., B. B. Bohren, and H. E. McKean. 1965. The haugh unit as a measure of egg albumen quality. Poult. Sci. 41:14611468 .
Ernst, E. 2010. Panax ginseng: An overview of the clinical evidence. J. Ginseng Res. 34:259-263.

Gillis, C. N. 1997. Panax ginseng pharmacology: A nitric oxide link? Biochem. Pharmacol. 54:1-8.

Han, K., I. C. Shin, K. J. Choi, Y. P. Yun, J. T. Hong, and K. W. Oh. 2005. Korea red ginseng water extract increases nitric oxide concentrations in exhaled breath. Nitric Oxide 12:159-162.

Hu, Y. J., Y. C. Lin, G. L. Zhou, and D. Q. Yu. 2003. Effect of Chinese extracts on performance and T lymphocyte cell subset of yellow broilers. China Poult. 12:14-17.

Jang, H. D., H. J. Kim, J. H. Cho, Y. J. Chen, J. S. Yoo, B. J. Min, J. C. Park, and I. H. Kim. 2007. Effect of dietary supplementation of fermented wild-ginseng culture byproducts on egg productivity, egg quality, blood characteristics and ginsenoside concentration of yolk in laying hen. Korean J. Poult. Sci. 34:271-278.

Jenkins, K. J. and A. S. Atwal. 1994. Effects of dietary saponins on fecal bile acids and neutral sterols, and availability of vitamins A and E in the chick. J. Nutr. Biochem. 5:134-137.

Jin, Y., V. S. Kotakadi, L. Ying, A. B. Hofseth, X. Cui, P. A. Wood, A. Windust, L. E. Matesic, E. A. Pena, C. Chiuzan, N. P. Singh, M. Nagarkatti, P. S. Naharkatti, M. J. Wargovich, and L. J. Hofseth. 2008. American ginseng suppresses inflammation and DNA damage associated with mouse colitis. Carcinogenesis 29:2351-2359.

Kang, K. S., T. Yokozawa, N. Yambe, H. Y. Kim, and J. H. Park. 2007. ESR study on the structure and hydroxyl radicalscavenging activity relationships of ginsenosides isolate from Panax Ginseng C. A. Meyer. Biol. Pharm. Bull. 30:917-921.

Kiefer, D. and T. Pantuso. 2003. Panax ginseng. Am. Fam. Physician 68:1539-1542.

Kim, C. S., J. B. Park, K. J. Kim,S. J. Chang, S. W. Ryoo, and B. H. Jeon. 2002. Effect of Korea red ginseng on cerebral blood flow and superoxide production. Acta Pharmacol. Sin. 23:1152-1156.

Kim, D. C. and M. J. In. 2010. Production of hydrolyzed red ginseng residue and its application to lactic acid bacteria cultivation. J. Ginseng Res. 34:321-326.

Kim, H., I, Oh, K. H. Park, N. M. Kim, J. H. Do, and Y. Cho. 2009. Stimulatory effect of dietary red ginseng on epidermal hydration and ceramide levels in ultraviolet-irradiated hairless mice. J. Med. Food 12:746-754.

Kim, Y. J., G. D. Lee, and I. H. Choi, 2015. Effects of dietary red ginseng marc on egg production, egg quality and blood characteristics of laying hens. J. Appl. Anim. Res. 43:242-246.

Lee, J. H. and S. H. Cho. 2011. Korean red ginseng extract ameliorates skin lesions in $\mathrm{NC} / \mathrm{N}$ ga mice: an atopic dermatitis model. J. Ethnopharmacol. 133:810-817.

Muwalla, M. M. and N. M. Abuirmeileh. 1990. Suppression of avian hepatic cholesterogenesis by dietary ginseng. J. Nutr. Biochem. 1:518-521.

NRC. 1994. Nutrient Requirements of Poultry. 9th rev. edn. National Academy Press, Washington, DC, USA.

Oakenfull, D. G. and G. S. Sidhu. 1990. Could saponins be a useful treatment for hypercholesterolaemia? Eur. J. Clin. Nutr. 44:79-88.

Park, E. K., M. K. Choo, M. J. Han, and D. H. Kim. 2004. Ginsenoside Rh 1 possesses antiallergic and anti-inflammatory activities. Int. Arch. Allergy Immunol. 133:113-120. 
Qureshi, A. A., Z. Z. Din, N. Abuirmeleh, W. C. Burger, Y. Ahmad, and C. E. Elson. 1983. Suppression of avian hepatic lipid metabolism by solvent extracts of garlic: Impact on serum lipids. J. Nutr. 113:1746-1755.

Rao, A. V. and D. M. Gurfinkel. 2000. The bioactivity of saponins: Triterpenoid and steroidal glycosides. Durg Metabol. Drug Interact. 17:211-235.

Rivera, E., S. Hu, and C. Concha. 2003. Ginseng and aluminum hydroxide act synergistically as vaccine adjuvants. Vaccine 21:1149-1157.

Shin, H. R., J. Y. Kim, T. K. Yun, G. Morgan, and H. Vainio. 2000. The cancer-preventive potential of Panax ginseng: A review of human and experimental evidence. Cancer Causes Control 11:565-576.

Sumiyoshi, M., M. Sakanaka, and Y. Kimura. 2010. Effects of red ginseng extract on allergic reactions to food in balb/c mice. J. Ethnopharmacol. 132:206-212.
Sung, W. S. and D. G. Lee. 2008. The combination effect of Korean Red Ginseng Saponins with Kanamycin and Cefotaxime against Methicillin-Resistant Staphylococcus aureus. Biol. Pharm. Bull. 31:1614-1617.

Szeto, Y. T., J. W. M. Wong, S. C. Y. Wong, S. C. Park, and I. F. F. Benzie. 2011. DNA protective effect of ginseng and the antagonistic effect of Chinese turnip: A preliminary study. Plant Foods Hum. Nutr. 66:97-100.

Thomas, D. V., A. L. Molan, and A. V. Ravindran. 2010. The ability of green tea to positively modify the gut microflora in broiler chickens. Aust. Poult. Sci. Symp. 21:203-206.

Wee, J. J., M. K. Park, and A. S. Chung. 2011. Biological activities of ginseng and its application to human health. In: Herbal Medicine: Biomolecular and Clinical Aspects (Eds. I. F. F. Benzie and S. Wachel-Galor). CRC Press, Boca Raton, FL, USA. pp. 157-174. 